\title{
Ran Hirschl*
}

\section{Early Engagements with the Constitutive Laws of Others: Possible Lessons from Pre-Modern Religious Law}

DOI 10.1515/lehr-2016-0003

Published online June 28, 2016

\begin{abstract}
Constitutional law and religious law are often portrayed as diametrically opposed domains. While there are obvious foundational differences between the two domains, the simplistic portrayal of religious law as altogether irrelevant to contemporary discussions about engagement with the laws of others provides an all-too-easy excuse for contemporary constitutional discourse to blind itself to religious law's rich history and doctrinal innovation. Alongside other possible new horizons of interdisciplinary inquiry, religious law may provide a fertile terrain for placing contemporary debates in (comparative) constitutional law in a broader context. In particular, few authors have paid close attention to the potential value of legal concepts developed within religious law to meeting the challenge of encounters with foreign law. Even fewer have drawn analogies between the effect of extradoctrinal factors on interpretation in the two domains. The poignant dilemmas of rejection of or interaction with foreign law yearn for thorough and prompt crossdisciplinary analysis, as their relevance to contemporary constitutional law comes to echo their historic importance in religious law. In this article, I explore elements of early engagement with the constitutive laws of others along two lines: (i) various doctrinal innovations in pre-modern religious law, particularly Jewish law, in respect to engagement with the laws of others; (ii) earthly motivations for change to religious law's treatment of external sources and practices. I conclude by suggesting that the current liberal constitutional canon's hostility toward religion, in particular its simplistic portrayal of religion as a monolithically "traditional," "particularist," "backward" and outdated domain runs the risk of throwing out the baby (religious law) with the bathwater (religion).
\end{abstract}

Keywords: religious law, constitutional law, Jewish law, interpretation, comparative law, comparative constitutionalism, interdisciplinary analysis

*Corresponding author: Ran Hirschl, Professor of Political Science \& Law, Canada Research Chair, Fellow of the Royal Society of Canada (FRSC), University of Toronto, Toronto, Ontario, Canada, E-mail: ran.hirschl@utoronto.ca 


\section{Introduction}

Contemporary discussions in comparative constitutional law and, more generally, comparative public law often proceeds as if there is no past, only present and future. Many of the debates that take place within the field are presented as grounded in ideas or situations that are novel and hitherto unknown to mankind. The world, however, was created before 1945, and even before 1787. The reality is that critical encounters with the constitutive laws of others have been taking place since well before the late eighteenth century. Many of the contemporary debates in comparative constitutional law have early equivalents, some of which date back over two millennia and many of which involve religious law. ${ }^{1}$ Granted, the particulars of current debates are indeed new. The migration of constitutional ideas, the ascendance of constitutional guarantees of rights and entitlements, the arrival of multiculturalism discourse and, subsequently, of its critics, the rise of a new transnational legal order and judicial class, and the corresponding decrease in the autonomy of "Westphalian" constitutionalism are among the developments that have inspired debates in public law over the last few decades. Taken as a whole, however, the history of engagement with the constitutive laws of others is much longer and richer than is reflected in the field's contemporary debates.

Canonical western constitutional discourse considers this wealth of early legal innovation, adaptation, and accommodation with respect to the laws of others to be largely immaterial, outdated, and altogether unrelated to contemporary constitutional theory, and, as such, unworthy of study, analysis, or reference. Accordingly, a one-sided mode of learning has developed, in which religious communities living in constitutional states are expected to pick up, adjust to, and even elevate themselves to the supposedly intellectual standards of canonical constitutional discourse, while the constitutional authority and its interlocutors are free to disregard, ignore, or even scorn religious law and its tremendously rich interpretive history. The intellectual construction of this disdain emerges from constitutional law's embedded hostility toward religion as an alternative system of laws, possessing its own symbols, and followers. It is fueled by the conceptualization of constitutional law as complete and perfect break from the legal governance of premodern public affairs. In this article, I question whether such learning should

1 See generally Ran Hirschl, Comparative Matters: The Renaissance of Comparative Constitutional Law (2014). 
remain unidirectional and consider which relevant ideas related to dealing with the laws of others may be learned from the centuries of debates within religious law doctrine, and practice, and which, if any, of these potential lessons may be applicable for today's struggles over the constitutional accommodation of religious difference.

There has been much debate in contemporary constitutional law about the unique nature of each polity's constitutional heritage and its prospects for withstanding the pressures of global convergence, and in particular about what, if any, external constitutional and transnational sources may be referred to in interpreting a given country's constitutional texts. Such debates, however, are anything but novel when considered in light of the history of pre-modern community-constituting law, most notably religious law. Pre-modern Canon and Shari'a law grappled with aspects of engagement with the outer legal universe, leading to rifts between inward-looking, "originalist," "textualist," or otherwise restrictive interpretive approaches and more cosmopolitan, adaptive interpretive schools. Nevertheless, because of the near-permanent "diasporic" state of the Jewish people, for thousands of years, Jewish law has evolved as an autonomous legal tradition without political sovereignty. Consequently, it has developed a particularly complex relationship with its legal surroundings, oscillating between principled estrangement and pragmatic engagement. In this sense, Jewish law provides an ideal context for studying the tension between principled objection to recognizing the legitimacy of other legal systems and the pragmatic acknowledgment of the inevitability of dealing with extra-communal law.

The Halakha generally takes a negative attitude toward other legal systems: although it recognizes non-Jewish law, it considers courts that base their rulings on such law illegitimate institutions. At the same time, the variety of social, economic, and political realities the Jews have been through since $c$. $70 \mathrm{CE}$ has given rise to a notably more pragmatic approach to non-Jewish law. The struggle between "authentic," "Hellenized," and later "Romanized" Judaism characterized the days of the Hasmonean dynasty, King Herod, and the Jewish-Roman wars. The Tanna'im (sages of the Mishna, c. 30-200 CE) addressed the relationship between Jewish law and the Roman legal system; the Babylonian Amora'im (the sages of the Gemara, c. 200-500 CE) contemplated measures to cope with petitions by Jews to Persian courts; and their successors, the Ge'onim of Babylonia (c. 600-1050 CE), dealt with Islamic law and its courts. Subsequent generations stretching all the way to Maimonides (in twelfth-century Spain) and the sixteenth-century Shulkhan Arukh (a codification of Halakha completed in Safed) by Rabbi Yosef Caro also frequently addressed the "principled pragmatism" duality informing Jewish law's approach to the laws of others. Even within each of these periods, considerable variation existed among Jewish communities 
regarding attitudes of engagement with foreign law, and the legitimacy of litigation before non-Jewish tribunals. ${ }^{2}$

This diversity and richness found within the Jewish tradition is complemented by the scope and depths of contributions throughout the pre-modern world. The wealth of knowledge and degree of theoretical sophistication found in this body of opinions, essentially a terra incognita for today's scholars of comparative constitutionalism, can add new angles to contemporary debates about engagement with the constitutive laws of others. In particular, exploring premodern religious law's encounters with other legal systems can help us develop a deeper understanding of the considerations and driving forces - principled, necessity-based, and/or ideology-driven - behind a legal system's selective engagement with foreign law and the "outer world" more generally. Such exploration may also help to generate some doctrinal and jurisprudential ingenuity for addressing the challenge of global constitutionalism. In the following pages, I explore elements of early engagement with the constitutive laws of others along these two lines.

In the first part of the article, I look at various doctrinal innovations in premodern religious law, particularly Jewish law, in respect to engagement with the laws of others. The examples considered in this section illustrate how selective encounters with the outer legal world, constitutional and otherwise, may be driven by a community's survival instinct developed in response to powerful canonization and convergence pressures. In the second part of the article, I look at some of the earthly motivations for change to religious law's treatment of external sources and practices. Similar motivations, I argue, may be at play in debates about the status of foreign sources in contemporary constitutional law. Illustrations are drawn from various religion-infused settings, near and far. These diverse examples are not meant to provide an exhaustive survey of all, or even most, areas where religious law may enrich or shed new light on conversations in contemporary comparative constitutional studies or debates about multicultural accommodation, a task that would easily fill several thick volumes. Rather, the goal of this article is more modest. Taken as a whole, the examples explored here suggest that the history of engagement with the constitutive laws of others holds more worth than current constitutional discourse and the trend toward convergence would have us believe.

2 See H.Z. (J.W.) Hirschberg, History of the Jews in North Africa: From the Ottoman Conquests to the Present Time 231-46 (Eliezer Bashan \& Robbert Attal eds., 1974); Uriel I. Simonsohn, A Common Justice: The Legal Allegiances of Christians and Jews Under Early Islam ch. 4 (2011); Gil Graff, Separation of Church and State, Dina de-Malkhuta Dina in Jewish Law, 1750-1848, at 18-29 (1985); Bernard Rosensweig, Ashrenazic Jewry in Transition 82 (1975). 
New arguments in comparative constitutional law that ignore religious law's rich interpretive legacy may therefore run the risk of being too flimsy and ahistorical to be considered truly novel. Moreover, these examples illustrate that alongside inquisitiveness per se, instrumentalist factors - from community survival to political economy - matter a great deal in explaining purportedly principled, doctrinal debates over convergence, resistance, and selective engagement (to paraphrase Vicki Jackson's terminology) with the constitutive laws of others, past and present.

I conclude by suggesting that the current liberal constitutional canon's hostility toward religion, in particular its simplistic portrayal of religion as a monolithically "traditional," "particularist," "backward” and outdated domain runs the risk of throwing out the baby (religious law) with the bathwater (religion). Even a cursory look at pre- and early-modern religious law suggests that there is much to appreciate and learn from early attempts to theorize about what today would be classified as key issues in comparative constitutional law. These early insights are particularly enlightening with respect to tensions between general practices and community traditions.

\section{Surviving the Laws of Others}

Much has been written over the last decade about the migration of constitutional ideas across legal systems, the rise of "constitutionalism beyond the state," or "transnational constitutionalism" and the formation of an Esperanto-like "generic" form of constitutional law (at least in relation to rights and liberties). As expected, these trends have not gone unnoticed. Domestic responses have ranged from full endorsement to outright resistance. In the United States, for instance, a lively debate has arisen over the legitimacy of judicial recourse to foreign or comparative law, and in the EU member states, nationalist opposition groups have voiced grave concerns about the threat to national sovereignty posed by the pan-European constitutional project. Meanwhile, anti-globalization activists oppose what they term the "new constitutionalism" - the largely "pernicious" spread of a set of quasi-constitutional supranational treaties and institutions that place global economic governance beyond democratic reach and promote uneven development by privileging transnational corporations at the expense of the world's economic hinterlands.

All these phenomena are portrayed in the comparative constitutional law literature as a manifestation of novelty, something that scholars of the laws of nations have never previously encountered. Granted, some of the specifics at 
play are indeed new, most notably the rise of a new transnational constitutional order and judicial class, and the corresponding decrease in the autonomy of "Westphalian" constitutionalism. But at least one central aspect of these developments - namely, the fundamental tension between forces of legal convergence and enduring patterns of divergence - is not novel.

At the most basic level, the idea of acknowledging the legitimacy and integrity of the constitutive laws of others has a long history. The Hellenic World (c. 600 BCE) is considered the cradle of experiments with constitutionalism. Solon is often credited with most of this constitutional ingenuity, as is Persia's Cyrus the Great, who is believed to have introduced the practice of religious toleration of minorities (c. 540 BCE). Plato compared the laws of the Greek city-states, and on the basis of this comparison, constructed what he deemed the ideal constitution. Aristotle, in Politics, likewise compared the constitutions of various city-states, and introduced a distinction between a polity's substantive constitution and its formal one. However, evidence of the concrete nature of constitutionalism in that era is sparse and possibly unreliable.

The earliest clear evidence of a concept that is significant for contemporary debates comes from Ptolemaic (Hellenic) Egypt (c. 300-30 BCE), where an official policy of legal diversity was introduced. Egyptian local law, or "the law of the land" (nomoi tes choras), applied to the indigenous population, whereas the Greek nomoi applied to Hellenic immigrants. In addition, royal decrees allowed the prosperous Jewish community of Alexandria to follow the "Law of Moses" in certain matters. ${ }^{3}$ The Roman Empire took a more assimilationist approach, but developed a distinction between jus civile, applicable to Romans, and jus gentium, the law of nations. Under the latter, the praetor peregrinus of the Roman Republic engaged in legal comparisons and consideration of foreign circumstances to settle disputes to which non-citizens were party. ${ }^{4}$

Similarly, the Charter of Medina - drafted by the Prophet Muhammad (c. 622 CE), founder of the first Islamic state - formed an alliance between several local tribes (that were not converted to Islam at that time) and Muslim emigrants from Mecca.

3 See Joseph M. Modrzejewski, The Jews of Egypt: From Ramses II to Emperor Hadrian (1995).

4 See Henry Clark, Jus Gentium, 16 Illinors L. Rev. 243 (1919). “The praetor peregrinus,” explains Henry Clark in his classic early twentieth century piece, studied the laws and legal theories of all cities, tribes, and nations, and extracted therefrom those rules and principles which were the best and most universal. These he published in a document called an edict. Each succeeding praetor was called upon to repeat this study and annually, upon taking office, to publish his edict. This system of laws so collected by the praetor peregrinus acquired the name of Jus Gentium. (Id. at 247). On acceptance of foreign law in the Roman Empire, see generally ANDREW M. Riggsby, Roman Law and the Legal World of the Romans 35 (2010). 
Importantly, the Charter distinguished between wars that required enlistment of all members of the polity, and Muslim wars from which non-Muslims were exempt. The idea of multiple legal identities in the pre-modern world reached its peak with the Moorish reign in al-Andalus (eighth to fifteenth century) and the Ottoman Empire's Millet system that allowed recognized religious communities to rule themselves under their own laws in matters of personal status and religious identity. In short, many polities throughout history have acknowledged the foundational laws of others and taken these laws into consideration.

Perhaps more importantly, several major waves of legal standardization throughout history - most notably the expansion of canon law that swept medieval Europe in the eleventh and twelfth centuries - have been religiondriven. Canon law is internal ecclesiastical law that governs the Roman Catholic Church, the Eastern Orthodox churches, and the Anglican Communion of churches. It deals mainly with matters of faith, morals, and discipline, although these areas have been broadly interpreted by church authorities to encompass numerous material aspects of life. The way in which canon law is legislated, interpreted, and at times adjudicated varies widely among the three bodies of churches it governs.

In all three traditions, however, the canon was initially a rule adopted by a central council or religious authority and later imposed over a vast territory by regional and local agents. In time, the study of canon law became a major scholarly discipline; through a continual process of precedent accumulation, elaboration, and interpretation, its various precepts were refined into an internally consistent code. ${ }^{5}$ Prominent legal historians now suggest that the initial streamlining and unification of religious law under canon law, and the expansion of its territorial applicability throughout much of medieval Europe planted the seeds of modern law, with its hierarchical structure and unified, central authority. Noted medievalists have argued that the structure of the medieval church and the medieval state (e. g., tensions between central and local government) also bore influence on the development of modern constitutional thought and institutions. ${ }^{6}$ Concurrently, Canon law's ontological and epistemological structure, modes of adjudication, and application are forebears of modern law in many respects as well.

Before this process of codification occurred, and until the eleventh century, most law was customary, and very little of it was written down. The migration of

5 Robert Ekelund et al., Sacred Trust: The Medieval Church as an Economic Firm 63 (1996); John Gilchrist, The Church and Economic Activity in the Middle Ages 12 (1969). See generally, John J. Coughlin, Canon law: A Comparative Study With Anglo-American Legal Theory (2011).

6 See Brian Tierney, Religion, Law, and the Growth of Constitutional thought 1150-1650 (1982). 
legal ideas was a routine, ordinary occurrence. In many respects, this was a golden age of practical (or applied) comparative legal studies, as legal systems did not enjoy complete hegemony, did not stress exclusivity, and were, for the most part, fairly tolerant of other legal systems. ${ }^{7}$ There were no problems of legislative sovereignty as there was typically no single legislative center; ${ }^{8}$ no professional judiciary, no professional class of lawyers, and no distinct "science" of law existed. As Harold Berman notes, there was "no independent, integrated, developing body of legal principles and procedures clearly differentiated from other processes of social organization and consciously articulated by a corps of persons specifically trained for that task." ${ }^{9}$ De facto legal pluralism was an everyday reality. As John Morrall writes: "It was common to find many different codes of customary law in force in the same kingdom, town or village, even in the same house, if the ninth century bishop Agobard of Lyons is to be believed when he says, 'It often happened that five men were present or sitting together, and not one of them had the same law as another.",10

But in the late eleventh and early twelfth centuries a wave of legalism spread throughout Europe. The main driving force behind this sudden transformation was the assertion of papal supremacy over the entire Western church and the push for church independence from secular control. This change, known as the Papal Revolution, was marked by a formal declaration by Pope Gregory VII in 1075. The so-called "investiture controversy," between the papacy and the Holy Roman Empire over authority to appoint church officials in the hinterlands, triggered a battle over the legal consolidation and control of Europe. Neither monarchs nor civil authorities were willing to accede to the declaration without a fight, and bloody wars were fought between the Holy Roman Emperor's faction (led by Henry IV) and the papal faction throughout Europe, with the latter emerging triumphant (Henry IV famously "walked to Canossa" in 1077 in contrition) toward the end of the twelfth century. Canon law, and with it modern law, was born. ${ }^{11}$

7 See Brian Tamanaha, Understanding Legal Pluralism: Past to Present, Local to Global, 30 Sydney L. Rev. 375 (2008).

8 Maurizio Lupoi, The Origins of the European Legal Order 429-436 (Adrian Belton trans., 2000).

9 See Harold J. Berman, Law and Revolution: The Formation of the Western Legal Tradition 50 (1983).

10 John B. Morrall, Political Thought in Medieval Times 17 (1962); a similar quote from a different edition of Morrall's book is cited in Tamanaha, supra note 7, at 378. On similarities in the character of Jewish law in mediaeval Ashkenazic communities, see, e. g., IsRaEl M. TA SHMA, Minhag Ashkenaz Ha-kadmon [“The Old Ashkenazi Custom”] (1992) [in Hebrew].

11 For comparing similar processes in medieval Jewish Law and possible non-Jewish influence on it, see Israel M. Ta Shma, Hasifrut Haparshanit La-Talmud [Interpretive Literature of the Talmud] (2000) [in Hebrew]. 
The unification process stretched across the reign of over 40 popes, from Leo IX (1049-54) to Boniface VIII (1295-1303). ${ }^{12}$ During this period, any nonchurch-controlled authority had to submit to the Church's complete spiritual and earthly dominance. During the reign of Pope Gregory VII (1073-85) the rationale given for this was that the Church is responsible for the world's salvation, and temporal power is subordinate to spiritual power. ${ }^{13}$ In 1204 , Pope Innocent III issued a decree that explicitly asserted the plenitudo ecclesiasticae potestatis, that is, the absolute and full power of the pope over all churches and the entire clergy. Innocent IV's canonists expanded this doctrine so that the pope was declared the vicar of Christ himself, the judge of all people, with power higher than and beyond any other spiritual or temporal authority. ${ }^{14}$

Because it was more or less universally applied, internally coherent, and cumulative, the church's canon law, which was administered by ecclesiastical courts overseen by bishops, enjoyed an advantage over its possible competitors. It claimed jurisdiction over most imaginable issues in criminal, civil, and family law and offered a relatively straightforward system of appeal up the ecclesiastical hierarchy toward Rome. ${ }^{15}$ As Berman notes, over the course of this process the "folk law" of the peoples of Europe disappeared almost completely and was replaced by, and consolidated into, sophisticated legal systems, belonging first to the church and later to secular political orders - canon law, urban law, royal law, mercantile law, and feudal and manorial law. Studies of concrete legal practices - for example, Marianne Constable's account of the English "mixedjury" doctrine that spanned from the Middle Ages to the nineteenth century - also reveal the disappearance of "law as practice," the actual usages and customs of communities, and its replacement with the law determined by officials. ${ }^{16}$ This convergence towards a clear, unified, hegemonic system, came at the expense of the diversity and tolerance inherent to these earlier uncodified, amorphous practices, bringing in serious concerns about minority cultural preservation. ${ }^{17}$

12 Luisa Giuriato, Succession Rules of the Latin Church, in The Political Economy of Theocracy 149 (Mario Ferrero \& Ronald Wintrobe eds., 2009).

13 Id.

14 Id.

15 BERMAN, supra note 9.

16 Marianne Constable, The Law of the Other: The Mixed Jury and Changing Conceptions of Citizenship, LAW, AND KNOWLEDGE (1994).

17 Convergence and constitutional responses to it are resonant contemporary issues as well: How can national constitutional traditions protect distinct identities against the sweeping waves of consolidation? One response is a dichotomous framing; countries including Argentina (1994) to the United Kingdom (1998) to Brazil (2004) and South Africa proactively include foreign/external 
Pre-modern law provides fascinating examples of "counter-hegemony" survival measures taken by religious minorities. These range from variations on mechanisms such as heresy, treason, and sedition, to the outright rejection and shunning of foreign laws, and in some cases to the adoption of fake identities. An extreme illustration of a survival-driven duality of religious norms is provided by Druze theology. The Druze - who currently number fewer than two million in total - broke away from Islam in the tenth century. They regard Caliph al-Hakim (eleventh century Egypt) as the human incarnation of the divine spirit and revere Nabi Shu'ayb (Jethro, the non-Jewish father-in-law of Moses) as prophet. Although they share many theological elements with Islam, the Druze do not consider the Prophet Muhammad the last of the prophets, do not fast during the month of Ramadan, and do not make a pilgrimage to Mecca. Having lived in a constant minority-religion status in largely Muslim societies, the Druze developed a concept of "presentation" (takiya) which allows them to present themselves outwardly (zahir) as members of the dominant or ruling religion while inwardly (batin) adhering to the unique elements of Druze faith. ${ }^{18}$

At the other end of the spectrum, outright rejection of foreign customs is the Hellenic portrayal of the Scythians - early Iranian nomadic tribes described by Herodotus as people who avoided all foreign customs. Farther east, stretches Zomia, a mountainous region the size of Europe that consists of portions of several Asian countries. "For two thousand years," argues political anthropologist James Scott, the disparate groups that now reside in Zomia have fled the projects of the organized state societies that surround them - slavery, conscription, taxes, corvée labor, epidemics, and warfare," thereby enabling the people of Zomia to defy state borders and maintain their de-facto autonomy and traditional way of life. ${ }^{19}$ Among the strategies employed by the people of Zomia to remain free from external interference were physical dispersion in rugged terrain; agricultural practices that enhanced mobility; use of pliable ethnic

jurisprudence in their constitutional frameworks. Conversely, there are attempts to prohibit foreign law, such as the "American Laws for American Courts" movement in parts of the United States particularly rallies against the incorporation or enforcement of Islamic Shari'a law by U.S. courts. See, e. g., Eugene Volokh, Foreign Law in American Courts, 66 Окцанома L. Rev. 219 (2014).

18 See generally Nissim Dana, The Druze in the Middle East: Their Faith, Leadership, Identity and Status (2003). An analogy may be drawn here to the anusim (coerced converted Jews) of late fifteenth century Iberia (today's Spain and Portugal).

19 James C. Scott, The Art of Not Being Governed: An Anarchist History Of Upland Southeast Asia (2009). The boundaries of Zomia are contested, but seem to include the highlands of Laos, Thailand, northern Vietnam, and Burma as well as southwest China, and some suggest also parts of northern India, Nepal, Pakistan, and Afghanistan. 
identities; devotion to prophetic, millenarian leaders; and maintenance of a largely oral culture that allowed them to reinvent their histories and genealogies as they moved between and around states. ${ }^{20}$

Contemporary thinkers who oppose any engagement with the constitutive laws of others surely do not think that a Zomia-like way of constitutional life is realistic or desirable. More nuanced approaches to dealing with the constitutive laws of others - arguably more relevant for today's transnational, seemingly "pluralist" constitutional setting - are also available. Jewish law in particular has developed sophisticated legal doctrines to allow Jewish communities, as semi-sovereign entities in exile, to maintain their religious identity for nearly two millennia while engaging selectively with the laws of others. The main thrust of these doctrines is a conceptual distinction between core, underlying, or basic elements of religious identity, and complementary aspects that under less-than-ideal circumstances may be compromised without violating those core pillars of identity.

At the foundational level, the Jewish legal tradition distinguishes between Jewish law (applicable to Jews) and the minimum moral requirements for the laws of all mankind..$^{21}$ Judaism recognizes 613 commandments (mitzvot) that Jews must follow. However, Judaism also postulates a binding corpus of universal law. According to the Jewish law tradition, before the theophany at Mount Sinai, the Noachide code (which was perceived as arising from an alliance between God and Noah - the ancestor of humanity after the Flood) governed all humanity; after God gave the Jews their own legal system, the Noachide code was to serve as the pillar of the laws of non-Jews. The Noachide code (Latin: praecepta Noachidarum; Hebrew: Mitsvot B'nei Noah), sometimes referred to as the "Seven Laws of Noah," includes six universal prohibitions - idolatry, blasphemy, bloodshed (i. e. homicide), illicit sexual relations, theft, and consumption of a limb torn from a living animal $^{22}$ - and a seventh positive commandment, dinin, which requires the establishment of courts and perhaps also the adoption of a civil legal code (broadly understood as a general obligation to institute a legal order allowing a regulated, fair, and honest social life). ${ }^{23}$ These Noachide commandments are considered universal, and adherence to them as a minimum requirement for any moral human society.

20 Id.

21 See Suzanne Last Stone, Sinaitic and Noahide Law: Legal Pluralism in Jewish Law, 12 Cardozo L. REv. 1157 (1991).

22 Even the dietary rule has its basic dignity rationale: whereas mankind may be carnivorous, humans must separate themselves from wild animals, which tear their meat from living animals.

23 The reference text is in the Babylonian Talmud treatise, Sanhedrin: 56b. 
Other intriguing distinctions abound. As noted Jewish law scholar Menachem Elon observes, there is an interdependence between Halakha's ritual commandments and its civil aspects. As Halakha has crystallized, it has recognized the "essential and fundamental distinction between issura [ritual law] and mamona [civil or "nonreligious" law], the latter generally corresponding to most of what is included in the corpus juris of contemporary legal systems. This basic distinction offer[s] greater flexibility and an extraordinary potential for development to the civil part of Halakha, that part which is most affected by, and subject to changes in economic and social life." 24 Additionally, the Talmud adopted another distinction, this one between biblical commandments, or halakhic requirements that are biblically mandated (mitzvot d'oraita, Aramaic for "directives by an ultimate authority" or "commandments of the Law of the Torah"), and rabbinic injunctions (mitzvot d'rabbanan, Aramaic for "directives by our rabbis"). And in the postTalmudic literature, a further distinction emerged between a rule (halakha) and a custom (min'hag or the "common practice").

Dating back to the third century CE, the doctrine of dina de-malkhuta dina (Aramaic for "the law of the kingdom is the law") is the halakhic principle which states that, with certain important caveats, the general law of the country where Jews reside is binding upon them, and, in certain cases, is to be preferred to Jewish law. ${ }^{25}$ The historical context that brought the Talmudic sage Shmuel to introduce the dina de-malkhuta dina doctrine is typical of the almost-permanently diasporic Jewish existence and the Jewish people's systemic need to respond and adjust to the laws of the land in which they resided. The Sassanid conquest of Babylonia (226 CE) under Ardashir I brought about an abrupt loss of Jewish political and religious autonomy; Jews were forced to adapt to the powerful and centralized rule of the Sassanids. In 241, Shapur I, son of Ardashir, successor to the throne, granted the minorities under his rule, including the Jews, cultural and religious autonomy. Shmuel, the Jews' leader at that time, instilled Babylonian Jewry with the notion that they ought to reconcile their form of community to the political context within which they were living. He then convinced the community to recognize the new Sassanid kingdom as a legitimate regime with decent and equitable laws which Jews, since they were to pay the regime imposed taxes, were bound to

24 Menachem Elon, The Legal Systems of Jewish Law, 17 N.Y.U. J. InT’L L. \& PoL. 221, 227 (1985); see also Elon's monumental work: Jewish Law: History, Sources, Principles, The Jewish Publication SocieTy ch. 4 (1994) (Hebrew edition, 1973).

25 An authoritative source on the doctrine and its origins, evolution, and application is SHMUEL Shilo, Dina D'Malkhuta Dina (1974). Elements of it may be found in Shmuel Shilo, Equity as a Bridge between Jewish and Secular Law, 12 CARDozo L. Rev. 737 (1990). 
obey. Over the centuries, dina de-malkhuta dina evolved into a fully-fledged doctrine governing the relationship of Jewish law and "gentile" law under which the Jewish communities lived.

As the doctrine evolved, a set of interpretive principles emerged detailing precisely which aspects of the "kingdom's law" were to be observed. These made clear that a law of the kingdom, if it is to be respected, must, among other requirements, derive from a legitimate or recognized authority, apply equally to all citizens, and not infringe upon any core religious injunction (the previously mentioned issura). The last of these requirements underscores that any law of the kingdom respected under dina de-malkhuta dina would be civil or "nonreligious" law; for example, the king's right to collect taxes, which was recognized in the Talmud, was also recognized by all halakhic authorities in the post-Talmudic period. Around the time of the aforementioned Shulkhan Arukh, an earlier restriction of dina de-malkhuta dina, which limited its application to ancient law, was relaxed. Some of medieval Jewish law's best interpretive minds, including Rabbeinu Tam (Rabbi Ya'acov ben Meir, c. 1100-1171), Nahmanides (Rabbi Moses ben Nahman Girondi, 1194-1270), and the Rosh (Rabbi Asher ben Yehiel, c. 1259-1327), developed sophisticated legal distinctions dealing with the permissibility of litigation before foreign tribunals. ${ }^{26}$ These interpretive moves allowed communities in late-medieval and early-modern times to adjust to the sweeping changes made to the legal systems around them as new nonreligious political entities began to form. ${ }^{27}$

A "principled pragmatism" approach has also been developed with respect to the closely related yet separate challenge of litigation before non-Jewish courts ("erka'ot shel goyim"). ${ }^{28}$ The principled aspect of this approach emerged from the fact that the ban on litigation in foreign courts was considered a core prohibition.

26 See Graff, supra note 2, at 27-28. On similar innovations in Babylonian and Persian Jewish communities, see Yaakov Elman, Babylonian Jews at the Intersection of the Iranian Economy and Sasanian Law, in Oxford HandBook of Judaism And Economics 545 (A. Levine et al. ed., 2010).

27 This dynamic is supported by other doctrines, such as kinyan situmta (see Bava Metsi'a 74a); it recognizes the practice of the merchants as valid according to Jewish Law. It thus may be seen as a possible path for recognizing civil law (including contracts) as binding. See Ron S. Kleinman \& Amal Jabareen, Transfer of Ownership in E-Commerce Transactions from the Perspective of Jewish Law: In Light of Israeli and American Law, in OxFoRd HANDBOOK OF JUdAISM AND ECONOMICS 499, 507-10 (Aaron Levine ed., 2010) (discussing “Jewish Law: Modes of Acquisition and Merchant Customs Principles and Concepts").

28 Whereas the dina de-malkhuta dina doctrine shares some core elements of what are today labeled "conflict of laws," the issue of litigation before gentile courts and the legitimacy of their verdicts is closer in nature to matters of "forum shopping," "full faith and credit," and other inter-jurisdictional problems of law, enforcement, and coordination. 
The prohibition was even stricter at times and places where Jewish communities enjoyed jurisdictional autonomy in personal-status laws (e.g. twelfth century Spain), and often also in commerce and criminal law. As we know, however, parties will engage in forum shopping whenever possible, and for much of the time the Jewish community was no exception. Voluntary litigation in "gentile" courts was quite common in medieval Ashkenaz (today's Germany), Italy, France, and Provence, where Jews enjoyed little jurisdictional autonomy. As the reality of Jewish-gentile relationships within a Muslim or Christian context became permanent, a reappraisal of the Talmudic attitudes and rules became necessary. As a result, a nexus of exemptions (e. g. a "mutual consent" rule, or a "salvation from the hands of gentiles" rule) was developed to ensure that the Jewish community's use of gentile courts was made "kosher."29

The Talmudic position on adopting the moral codes of others is quite clear. Leviticus (18:3) states that "You shall not copy the practices of the land of Egypt where you dwelt, or the land of Canaan to which I am leading you; nor shall you follow their laws" ("u'vekhukoteihem lo telekhu"; literally: "and their laws you shall not walk/follow"). And Leviticus (20:23) states (in the context of immoral sexual behavior): "You shall not follow the practices of the nations [khukot ha'goy; literally "the constitutions of the gentiles"] that I am driving out before you. For it is because they did all these things that I abhorred them." The early Mishna extends the concept of khukot ha'goy to include forbidden practices not listed in Leviticus and ranging from idolatrous or immoral associations to superstitious and magical practices termed "the ways of the Amorites" ("darkhei ha'emori"). ${ }^{30}$ All of these distinctive strategies, teasing out the nuances between biblical and rabbinic injunctions, created a strong and durable framework for retaining Jewish identity as a minority community. Not only did they establish boundaries between distinct, yet superimposed, relevant legal conventions, but they also created paradigms for social coexistence between majority and minority culture. ${ }^{31}$

29 See Graff, supra note 2, ch. 1; R. Simcha Krauss, Litigation in Secular Courts, 2 J. Halacha \& Contemporary Soc. 35 (1982).

30 See Gideon Bohak, Ancient Jewish Magic, A History 356 (2008). One of the important practical implications of the Mishna's specification of forbidden practices was in the area of medicine; as Boahk explains, "once the rabbis declared that anything which heals is not 'the Ways of the Amorites', they opened a wide door for the entry of numerous foreign customs, as long as they were deemed by knowledgeable experts, or by the rabbis themselves, to have real medical value" (Id. at 384-85).

31 A present-day equivalent is instances of religious interpretive schools awarding broader recognition to civil law. See, e.g., Avishalom Westreich \& Amihai Radzyner, Civil Marriage in Israel Following the Noahide Decision: A Debate, 6-7 Family L. Rev. 1 (2014) [in Hebrew]. 
One of history's little ironies is that unlike today's comparative constitutional law or even the Supreme Court of Israel (which draws on Jewish law for primarily ornamental purposes), major legal thinkers of the sixteenth and seventeenth century - think Erastus, Grotius and Selden, none of whom, needless to say, was Jewish - viewed the sophisticated distinctions developed within Jewish law with respect to the laws of others as an ideal-type benchmark against which to develop their views about natural law, the boundaries of religious toleration and the faith of others, differentiation between core tenets of belief that may not be compromised and precepts amenable to some flexibility, and the relations of civil and ecclesiastical authority more generally. ${ }^{32}$ Their high regard for Jewish law was unflagging.

In arguing that the church lacks an independent power of excommunication (Treaties of Erastus, 1589), Erastus - a Swiss theologian - regarded the "commonwealth" of the Hebrews as an expression of God's own political preferences. Accordingly, he announced that "that Church is most worthily and wisely ordered, which cometh nearest to the constitution of the Jewish Church." 33 Likewise, in his search for a God-given constitution against which to evaluate the relations between civil and religious authority of his time, Hugo Grotius invokes the laws of the Jews as a prime example. "If, however, there is somehow to be found a republic which could rightly point to the true God as its founder," Grotius writes, "then this must clearly be the one that all other ones should set themselves to imitate and seek to resemble as closely as they can." From this, notes historian of political thought Eric Nelson, it follows that "if God himself had designed a commonwealth, then the constitution of that republic would be perfect and authoritative. And, as Grotius promptly adds, God did design such a commonwealth: the republic of the Hebrews."34

John Selden (a British parliamentarian, also known for his contributions to political theory and the international law of the sea) devoted half of his adult life to a meticulous study of Jewish law and the Noachide precepts as a possible

32 On the significant impact of Jewish sources, Biblical and rabbinical, on European political thought in the seventeenth and eighteenth century, see Eric Nelson, The Hebrew Republic: Jewish Sources and the Transformation of European Political Thought (2010). Earlier accounts pointed to the possible influence of Jewish sources on the development of international law. See, e.g., Shabtai Rosenne, The Influence of Judaism on the Development of International Law, 5 Netherlands L. Rev. 119-49 (1958).

33 See Eric Nelson, The Religious Origins of Religious Toleration, in The Templeton Lecture on RELIGION AND WORLD AfFAIRS 5-6 (2010), http://www.fpri.org/docs/media/201105.nelson.religiousoriginsofreligioustolerance.pdf.

34 Id. at 7. 
template for universal legal norms applicable to all mankind. ${ }^{35}$ In 1613 , to pick another example, Grotius (then acting in the role of legal counselor of the Netherlands) wrote an edict (Decretum pro pace ecclesiarum) advocating a policy of toleration where only the basic tenets necessary for underpinning civil order (e.g. the existence of God and His providence) ought to be enforced, with differences in obscure theological doctrines left to private conscience and beyond state control. The Israelite example - often referred to as respublica hebraeorum, the "republic of the Hebrews" - was deployed to defend Erastianism (state control of religious affairs) and toleration (core tenets are to be enforced; malleable precepts may be subjected to discretion and interpretation). Applying these rationales to religious divisions of his time, Grotius suggested that the core truths of Christianity held in common by Catholics, Calvinists, Lutherans, and Arminians, were "fundamentally more important compared to the peripheral points on which they felt they differed."36

Distinctions between foundational and supplementary values in religious law remain relevant to contemporary debates in comparative constitutional jurisprudence. One intuitively thinks of distinctions between jus cogens-like norms in constitutional law (decisive principles or norms from which no derogation is permitted) and other, softer norms, where expressions of particular constitutional identity or deference to local traditions may be legitimate. Likewise, such distinctions play a central role in the constitutional jurisprudence of religion-imbued settings, where the question of which religious precepts will be protected by the state occupy the constitutional domain.

Fast-forwarding to today, consider the constitutional interpretation of "Islamic provisions" in predominantly Muslim countries. In 1980, Egypt amended Article 2 of its Constitution (originally adopted in 1971) to introduce Shari'a as "the" (instead of "a”) primary source of legislation; this provision was reproduced in the 2012 constitution introduced by the since-ousted Muslim Brotherhood regime, and again in the 2014 Constitution. Egypt's courts have thus been grappling for over 30 years with the contested status and role of Shari'a as a potentially authoritative source of laws. To address this question in a moderate way, Egypt's Supreme Constitutional Court (SCC) developed an innovative matrix of religious directives - the first of its kind used by a non-religious tribunal. This model warrants that the state must obey any

35 See Jason P. Rosenblatt, Renaissance England’s Chief Rabbi: John Selden (2006); G. J. Toomer, 1 John Selden: A Life in Scholarship (2009).

36 See Editorial: Grotius and the Natural Law Tradition, 1 Literature of Liberty: A Review of Contemporary Liberal Thought 4 (1978). 
unambiguous scriptural rule that scholars have found in the Qur'an or a trustworthy hadith; however, the state is not obliged to follow secondary interpretations or principles that have been extrapolated from scriptural rules but which are one of several logical meanings that can be ascribed to them. ${ }^{37}$ The distinction between putatively undisputed, universally binding principles of Shari'a and flexible applications of those principles stands at the heart of the Court's Islamic review. ${ }^{38}$ Legislation that contravenes a strict, unalterable principle recognized as such by all interpretive schools is declared unconstitutional and void, while at the same time ijtihad (reasoning or external interpretation) is permitted in cases of textual lacunae, or where the pertinent rules are vague, open-ended, or subject to various acceptable interpretations. The Egyptian SCC's two-tier hierarchy of Shari'a norms has allowed it (along with the Supreme Administrative Court) to issue moderate or liberalizing rulings on contested matters such as the use of religious attire in the public school system, the scope of Islamic banking restrictions, and Islamic divorce procedures. ${ }^{39}$ The common rationale in all these rulings is essentially that since there is no consensus among religious authorities on the centrality of the practice, the state is not obliged to follow it in order to remain sufficiently "Islamic."

Similar distinctions exist in other Islam-infused jurisprudential settings, ranging from Tunisia to Indonesia. A two-tier conceptual matrix similar to that deployed by the Egyptian Constitutional Court allowed Habib Bourguiba, the first president and great modernizer of Tunisia, to adopt the Personal Status Code in 1956; this was arguably the most liberal personal-status legislation adopted by a country that is constitutionally committed to the teachings of Islam. The same interpretive flexibility led to further modernizing revisions

37 Clark B. Lombardi, State Law as Islamic Law in Modern Egypt: The Incorporation of the Shari'a into Egyptian Constitutional Law 48 (2006).

38 Clark B. Lombardi, Islamic Law as a Source of Constitutional Law in Egypt: The Constitutionalization of the Sharia in a Modern Arab State, 37 Columbia J. Tran'L L. 81 (1998); Nathan J. Brown, Islamic Constitutionalism in Theory and Practice, in Democracy, the Rule of LaW AND IsLam 491 (Eugene Cotran \& Adel Omer Sherif eds., 1999).

39 For a prime example, see Wassel v. Minister of Education (the niqab [veil] case), Case No. 8 of the $17^{\text {th }}$ Judicial Year (May 18, 1996) (Egypt); a translation into English is available at NAthan J. brown \& Clark B. Lombardy, Translation The Supreme Constitutional Court of Egypt on Islamic Law, Veiling and Civil Rights: An Annotated Translation of Supreme Constitutional Court of Egypt Case No. 8 of JUdicial YeAR 17 (May 18, 1996) 21 Am. U. Int'l L. Rev. 437 (2006). See also Riba [usury or interest] Case; Decision No. 20, $1^{\text {st }}$ judicial year, and Decision 28, $2^{\text {nd }}$ Judicial Year (May 4, 1985) [Egypt]; Khul Law Case, Constitutional Case No. 201, 23 ${ }^{\text {rd }}$ Judicial Year (Dec. 26, 2002) (Egypt). 
of the Code in $1993 .^{40}$ In a landmark 2009 case, Kuwait's Constitutional Court ruled that women lawmakers do not have to wear the hijab while in parliament. Since Shari'a law is not unified in its approach to the headscarf, the Court reasoned, one cannot fairly conclude that wearing the hijab is the only possible interpretation of the "compliance with Islam" clause in a 2005 law that allows women to vote and run for parliament. ${ }^{41}$ Likewise, in a landmark ruling that struck down the proposed establishment of an "Islamic morality" (hisba) police in the North-West Frontier Province (NWFP), the Supreme Court of Pakistan ruled that "Islamic jurists are unanimous on the point that except for sallat [prayer] and zakat [alms] no other religious obligation stipulated by Islam can be enforced by the state." ${ }^{42}$ Much like its Egyptian counterpart, the Court suggested that there is no consensus within Islamic jurisprudence that state enforcement of religious values is warranted.

Granted, the motivating force behind many of these decisions is the containment of religion and the protection of human rights, not acceptance of legal pluralism or encounters with "different" legal systems as such. However, as these examples vividly illustrate, concepts and distinctions developed within religious law may be tapped to address contemporary challenges involving clashes between the constitutional order and rival religious norms or claims.

India's rich constitutional jurisprudence on religion provides a different illustration of the conceptual distinction between essential elements of religion and supplementary or voluntary aspects of it. Article 25 of India's constitution (1950) protects "Freedom of conscience and free profession, practice and propagation of religion." Through numerous rulings over the years, the Supreme Court of India has developed a sophisticated interpretive framework to delimit the scope of religious practice protected under Article 25. In a nutshell, it provides a two-tier matrix according to which the constitutional protection of religious practice extends only to religious practices considered "essential" or "integral" to a particular religion but not necessarily to practices not considered indispensable to a given denomination's core. In the Court's words: "protection under Article 25 extends a guarantee for rituals and observances, ceremonies and modes of worship which are integral parts of religion and as to what really

40 See Amira Mashhour, Islamic Law and Gender Equality - Could There Be a Common Ground? A Study of Divorce and Polygamy in Shari'a Law and Contemporary Legislation in Tunisia and Egypt, 27 Hum. RTs. Q. 562 (2005).

41 Ministry of Islamic Affairs v. Rola Dashti and Aseel al-Awadhi, Constitutional Court of Kuwait, Decision of Oct. 28, 2009 (Kuwait).

42 Reference 2/2005 In Re: NWFP Hisba Bill, P.L.D. 2005 S.C. 873 (Pakistan). 
constitutes an essential part of religion or religious practice has to be decided by the courts with reference to the doctrine of a particular religion or practices regarded as parts of religion." 43

In Acharya Jagdishwaranand v. Commissioner of Police, Calcutta (1984), the Supreme Court of India held that the performance of tandava dance (a symbolic dance involving skulls, firearms, spears, and tridents) in public places was not an "essential" practice for the Anand Margis spiritual movement. ${ }^{44}$ In T. V. Narayana v. Venkata Subbamma (1996) the court upheld a law abolishing "the hereditary right to appointment as an archaka" (an estate or a will execute) as this right was not an essential aspect of the Hindu religion. ${ }^{45}$ Questions have also arisen as to whether cow sacrifice by Muslims on Bakr-Id (Eid al-Adha) day is an essential practice in Islam. As is well known, veneration for the cow exists among most Hindu groups and, in the Indian context, this is sometimes pitted against the ritualistic animal sacrifice associated with Muslim festivals such as Bakr-Id. In all of its rulings on the matter, the Court has held that the pertinent Islamic precepts say that cows are merely one type of animal that may be sacrificed, so that their sacrifice is not a core practice. ${ }^{46}$ In a later decision on the matter, the Supreme Court reiterated that a total prohibition on the slaughter of the progeny of cows does not violate Article 25 of the constitution, as the sacrifice of cows per se is not essential to Islam. ${ }^{47}$ More recently, the Supreme Court of India questioned how essential to Hinduism is the notion of excluding women from a holy prayer place. The case involved a constitutional challenge to the practice of the Sabarimala Temple in the Indian state of Kerala to prohibit women between the ages of ten and fifty from entering the temple. Stating that affirmation of the constitutionality of the practice would put "gender justice in danger" the Supreme Court urged the temple's governing body to provide evidence that such an exclusionary custom has existed for centuries as the temple authorities claim, as well as to show that it was and remains "essential" to religious practice. ${ }^{48}$

43 N. Adithyan v. Travancore Devaswom Board AIR 2002 SC 106 (India).

44 Acharya Jagdishwaranand v. Commissioner of Police, Calcutta AIR 1984 SC 51 (India).

45 T. V. Narayana v. Venkata Subbamma AIR 1996 SC 1807 (India).

46 See, e. g., Mohd. Hanif Qureshi v. State of Bihar AIR 1958 SC 731 [India]; State of West Bengal v. Ashutosh Lahiri AIR 1995 SC 464 (India).

47 State of Gujarat v. Mirzapur Moti Kureshi Kassab Jamat (2005) 8 SCC 534 (India).

48 Indian Young Lawyers Association v. State of Kerala, WP 373/2006 (India). See Radhika Agarwal and Devika Agarwal, The Right to Enter Places of Worship: When God is Neutral, is Gender Discrimination Justified? InT’L J. Const. L. Blog, Apr. 6, 2016. 
At the same time, the Supreme Court of India also ruled, in the landmark case of Bijoe Emmanuel v. State of Kerala (1986), that Jehovah's Witness students may be exempt from singing the national anthem at school, since compelling them to join in would violate their "genuine, conscientious religious objection" to doing so. ${ }^{49}$ Lower courts have taken note of the Supreme Court of India's two-tier matrix for accommodating religion. Having carefully examined scholarly opinion and detailed evidence, the Punjab High Court agreed in the high-profile case of Gurleen Kaur v. State of Punjab \& Haryana (2009) that a Sikh school's decision to deny admission to students who had shorn off their hair and plucked their eyebrows deserved constitutional protection, since having uncut hair is an essential requirement of Sikhism. The court stressed in reaching its decision that "retaining hair unshorn is an essential component of the Sikh religion... Maintaining hair unshorn is a part of the religious consciousness of the Sikh faith."50

A similar distinction between mandatory and commendable practices informs the approach adopted by the Supreme Court of Malaysia (now renamed the Federal Court of Malaysia) to evaluating whether constitutional protection ought to be assigned to a religious practice. That Malaysian court has interpreted "the right to practice religion" as the right to perform "essential and mandatory practices to that religion.” In the leading case on the question of religious attire in the public sector (Kamaruddin v. Public Service Commission Malaysia, 1994), the Federal Court of Malaysia applied the "mandatory practice test" developed by the Supreme Court of India in order to determine that the purdah (in this case referring to a veil-like head and neck cover, but in the general sense, female seclusion) worn by a Muslim woman while at work in public service may be restricted by law on the basis of public interest, since it is a non-mandatory practice within Islam. ${ }^{51}$

In 2006, the Federal Court of Malaysia upheld the constitutionality of the School Regulation Act (1997), which prohibited the wearing of the turban (serban) as part of the school uniform, since "th[is] 'practice' was of little significance from the point of view of the religion of Islam."52 The Court made clear that if the practice in question is compulsory or "an integral part" of the religion, courts should give it more weight but, if it is not, they should assign it less weight: "In the Islamic context, the classification made by jurists on the

49 Bijoe Emmanuel v. State of Kerala AIR 1987 SC 748 (India).

50 Gurleen Kaur v. State of Punjab (High Court of Punjab and Haryana), decision released on May 30, 2009 (India).

51 Kamaruddin v. Public Services Commission Malaysia [1994] 3 MLJ 61 (Malaysia).

52 Meor Atiqulrahman Ishak et al. v. Fatimah Sihi et al., 4 CLJ 1 (2006) (Malaysia). 
'hukum' (meaning or command) regarding a particular practice will be of assistance. Prohibition of a practice which is 'wajib' (mandatory) should definitely be viewed more seriously than the prohibition of what is 'sunat' (commendable)." Wearing the turban, the Court held, does not belong to the first category of practices. In support of this two-tier matrix for classifying religious practices within Islam, the Malaysia's Federal Court referenced landmark Supreme Court of India cases articulating the "integral part of religion" test. ${ }^{53}$ A similar approach was later invoked by the Supreme Court of Bangladesh in its leading decision on Islamic religious attire in the public sector. ${ }^{54}$

Analogous logic is differently applied in the European Court of Human Rights' use of the "margin of appreciation" doctrine in cases involving freedom of religion. ${ }^{55}$ Lautsi $v$. Italy (2011) offers a textbook example. The earlier decision of the ECtHR's 7-judge Chamber (Lautsi I) held that the mandatory display of the crucifix in Italian public school classrooms breached Italy's obligations under the European Convention of Human Rights. This ruling was portrayed in Italy as an all-out war against Italy's national meta-narrative and religious heritage, and provoked widespread outrage. The Italian Prime Minister, for example, stated that "this decision is not acceptable for us Italians. It is one of those decisions that make us doubt Europe's common sense." 56 The Vatican accused the Court of having delivered a "short sighted and ideological" decision. ${ }^{57}$ In Lautsi II, the ECtHR's 17-member Grand Chamber overturned the Chamber's ruling in Lautsi I. It rejected the human rights claim of a Finnish-born mother residing in Italy

53 Among the Supreme Court of India decisions cited were: The Commissioner, Hindu Religious Endowments, Madras v. Sri Lakshmindra Thirtha Swamiar AIR 1954 SC 282 (India); Sardar Syedna Taher Saifuddin Saheb v. State of Bombay AIR 1962 SC 853 (India); T. V. Narayana v. Venkata Subbamma AIR 1996 SC 1807 (India); Javed v. State of Haryana AIR 2003 SC 3057 (India).

54 Supreme Court Writ Petition 4495/2009 Advocate Salahuddin Dolon v. Bangladesh (Jun. 28, 2009) (Bangladesh).

55 The Council of Europe defines "margin of appreciation" as the wiggle room granted by the Strasbourg organs to national authorities to fulfill their obligations under the European Convention on Human Rights. From a jurisprudential standpoint, the margin of appreciation is a judicial doctrine whereby supra-national courts allow states to have a measure of diversity in their interpretation of human rights treaty obligations, based on local traditions, heritage, and context. If a matter is of utmost significance to a given member state (one might think of core collective identity policies, practices and symbols as falling in that category) a reasoned deference towards it ought to be expressed. See, e. g., Leyla Şahin v. Turkey, App No. 44774/98, Eur. Ct. H.R. (Grand Chamber Nov. 10, 2005).

56 Quoted in Susanna Mancini, The Crucifix Rage: Supranational Constitutionalism Bumps Against the Counter-Majoritarian Difficulty, 6 Euro. Const. L. Rev. 6, 6 (2010).

57 Id. at 7. 
who objected to the display of religious symbols (crucifixes) in her sons' public school. ${ }^{58}$ Rather than requiring state schools to observe confessional neutrality, the Court upheld the right of Italy to display the crucifix, an identity-laden symbol of the country's majority community, in the classrooms of public schools. Using the margin-of-appreciation concept, Europe's highest human rights court held that it is up to each signatory state to determine whether to perpetuate this (majority) tradition. The crucifix was taken to be so central to Italian collective identity that Italians themselves were responsible for deciding its status.

In Professor Joseph Weiler's pro bono intervention before the Grand Chamber on behalf of eight European governments that opposed a ban on the display of crucifixes in Italian classrooms, he maintained that no consensus exists throughout Europe with respect to the accommodation of religious symbols in the public sphere. In France, a strict policy of secularism (laïcité) has long been in place; in Poland and Malta, Catholicism has been a part of the collective identity; in Scandinavia, the Evangelical Lutheran Church is the "state church"; in England, the monarch is "Supreme Governor" of the Church of England and "Defender of the Faith"; and the national flags of various European countries feature a Christian cross. In the face of such multiplicity, Weiler suggested that the ECtHR ought to avoid imposing a one-rule-fits-all policy on all Council of Europe member states (with their combined 800 million strong population), and ought instead to defer to integral local values and traditions. In short, the default in non-consensus situations should be deference toward core national collective identity values and practices, self-proclaimed by the member states as such. The Grand Chamber concurred.

Would analogous "two-tier" hierarchies of rules - hierarchies that distinguish foundational, unambiguous constitutional values from malleable, supplementary preferences - prove helpful in avoiding the rigid dichotomy between full endorsement and outright rejection of foreign law? Might a similar logic be drawn upon to facilitate a given country's efforts to maintain its constitutional identity while at the same time incorporating transnational constitutional values that are not deemed threatening? And might it be helpful in thinking creatively about the boundaries of accommodating religious difference within a modern state or about the relations between individual countries and international human rights regimes? These and other related questions require a far more meticulous inquiry than I am able to offer here. One thing seems clear though: the pre- and early-modern world of religious law might prove helpful in

58 Lautsi and Others v. Italy, App No.30814/06, Eur. Ct. H.R. (Grand Chamber Mar. 18, 2011). 
answering these questions, since it offers ample illustrations of the frictions that arise from states' and communities' inevitable engagement with the constitutive laws of others and of the potential responses to those frictions. As I hope to have shown, pre- and early-modern religious law, different as it undoubtedly is from today's constitutional domain, ought not be instantly dismissed as irrelevant when searching for answers to such questions. In its struggle for survival amid pressure from rival legal systems, religious law provides a vivid illustration of how creative jurisprudential concepts and distinctions can help us move beyond prevalent yet overly simplistic love-hate attitudes toward the constitutive laws of others.

\section{The Social and Political Context of External Engagement}

Necessity may well be "the mother of invention," as the proverb attributed to Plato (Republic) goes. However, doctrinal attitudes toward engagement with the constitutive laws of others may be informed, not just by pure necessity or survival instincts, but also by earthly, even instrumentalist, considerations. That interpretation matters a great deal in constitutional law is not news; examples abound. Interpretation has likewise been a cornerstone of religious law. Everyone who follows Jewish law, for instance, is familiar with the long interpretive journey traversed around the Jewish dietary prohibition against eating meat and dairy together, from the Torah verses that tell us not to "boil a young goat ( $\left.g^{\prime} d i\right)$ in its mother's milk" to today's complex labyrinth of rules concerning kosher foods. ${ }^{59}$ However difficult it is to amend a venerable constitution that has acquired a "larger than life" status, sacred texts are outright impossible to amend (and are seldom replaced with others). Therefore, doctrinal adjustments made via interpretation seem even more crucial to religion than they are to constitutional law. It is hardly surprising, then, that fierce interpretive struggles have come to dominate the translation of sacred directives into

59 Exodus 23:19; Exodus 34:26; Deuteronomy 14:21. The prominent $11^{\text {th }}$-century Talmudic commentator Rabbi Shlomo Yitzhaki (Rashi) suggested that g'di must refer to a broader category of kosher mammal offspring, e. g. calves and lamb. Other Talmudic sources suggested that because it was difficult to distinguish between domesticated kosher animals and other meats, there should be a generic prohibition of dairy and any kosher animal meat except fish. The rest is history, as the saying goes. 
practical guidelines for private and public life. In fact, one could argue that the main reason the domain of religion has seen so many internal interpretive struggles over the centuries is precisely that sacred texts - while often relatively easy to interpret or distort - are impossible to amend. ${ }^{60}$

When a novel legal question presents itself, a religious authority, much like a constitutional judge, may look to draw inferences from verdicts handed down in analogous situations within the corpus of the religion's sacred texts and canonical secondary sources; or it may opt to incorporate external solutions that are compatible with the religion's core values. ${ }^{61}$ Both routes involve a fair amount of results-driven "cherry-picking." Religious interpreters throughout history, like some of today's philosopher-king constitutional court judges, often relied on discerning readings of sacred texts to advance their worldviews and preferences. The entire domain of religious law, one could argue, offers the most spectacular example of the living-tree - "a tree of life," as the Book of Proverbs puts it - approach to interpretation. And there are striking parallels largely, alas, underexplored and under-theorized - between the interpretation of sacred texts and of constitutional texts. ${ }^{62}$ Abstract as they may be, these parallels may shed light on the forces that drive the purportedly principled debate concerning the importance of interaction with foreign law.

Like most constitutional provisions, the wording of almost all religious imperatives is open-ended and subject to various interpretations. ${ }^{63}$ Driven by an instinct to remain relevant and to increase or maintain their support base, and by a need to find plausible ways to address widening gaps between traditional interpretations and changing realities, rather than limiting themselves strictly to principled theological discourse, framers and interpreters of religious law have long taken social and economic factors into account. Indeed, the history of religious interpretation is filled with examples of such internal adjustment and adaptation to exogenous changes.

Jewish law, in particular, has been conducive to ingenuity and change driven by social and economic needs. It has evolved mainly through a living-tree

60 See generally Moshe Halbertal, Interpretative Revolutions in the Making 168-204 (1997) [in Hebrew]. There are however some areas where interpretation of religious sources is stalled or "blocked" for ideological or political reasons. See, e.g., Avishalom Westreich, The Gatekeepers of Jewish Family Law: Marriage Annulment as a Test Case, 27 J. L. \& Religion 329 (2011).

61 See Shilo, supra note 25; Jeffrey I. Roth, Crossing the Bridge to Secular Law: Three Models of Incorporation, 12 CARDOZO L. REv. 753 (1991).

62 For a primer on this issue, see Thomas Grey, The Constitution as Scripture, 37 StAN. L. REv. 1 (1984). 63 Interestingly, not all religious traditions follow a logic similar to the common law's stare decisis, a fact that also makes the interpretative field even more open and potentially contested. 
approach to interpretation. The best interpretive minds throughout the last two thousand years of the Jewish tradition - Maimonides being one pertinent example - spent most of their intellectual energy debating possible changes to the law that were meant to respond to variance in geographic conditions among communities or to changing social and economic conditions. ${ }^{64}$ The Talmud, Mishnah, and other halakhic literature exhibit rich legal casuistry aimed at demonstrating how certain interpretations and practices that reflect social change or economic necessity do not, in fact, oppose pertinent religious rules, despite appearances to the contrary. ${ }^{65}$

As Menachem Elon observes, an enormous mass of materials, comprising hundreds of thousands of legal opinions and responsa covering all areas of Jewish law, came into being "against the background of, and as a result of, the application of Jewish law to practical, day-to-day life." 66 Furthermore, the areas of law that preoccupied the Jewish community and its leadership were those most affected by social and economic change. Because many religious directives were based on the experience of simple agrarian societies or otherwise premodern markets, adaptation to modern states and markets was inevitable. ${ }^{67}$ As Elon explains, "The Halakhic authorities and the lay leadership were required to respond to these changes and supply new solutions."68 In many instances adaptation involved separating a precept's telos (in the Aristotelian sense of "purpose" or "goal") from the concrete narrative or context within which it exists in the sacred texts. In this way the talented interpretive minds were able to assign new meanings to old verses.

Although environments, circumstances, and conditions are not the only reason for variance among legal systems, they do play a role. For example, even though it is normally forbidden for a Jew to instruct a non-Jew to work on the Sabbath, Jewish communities in very cold climates (Northern and Eastern Europe) permitted Jews to ask a non-Jew to heat their homes on that day. Similarly, the daily afternoon prayer and the evening prayer were combined

64 See generally Stephen D. Benin, The Search for Truth in Sacred Scripture Jews, Christians, and the Authority to Interpret, in With Reverence for the Word Medieval Scriptural Exegesis in Judaism, Christianity, and Islam 13-32, 17 (J. Dammen et al. eds., 2003).

65 See Suzanne Last Stone, On the Interplay of Rules, Cases, and Concepts in Rabbinic Legal Literature: Another Look at the Aggadot on Honi the Circle-Drawer, 24 DinÉ IsRael 125 (2007).

66 Elon, supra note 24, at 231.

67 See Suzanne Last Stone, Religion and State: Models of Separation within Jewish Law, 6 InT'L J. Const. L. 631 (2008).

68 Elon, supra note 24, at 232. 
into one afternoon praying session in Jewish communities in northern Germany because darkness fell in the early afternoon during winter, so that attendance at the separate evening prayer was minimal. ${ }^{69}$ And while Maimonides, who lived in Muslim Spain and later Egypt, ruled that a married woman who failed to carry out her wifely duties might be physically chastised by a Jewish court, Jewish communities in Christian Europe were horrified at the very thought of it, possibly revealing the influence that majority culture practices and customs in different places have on rabbinic interpretation of religious mores. ${ }^{70}$ To take yet another example, the attitude of Jewish communities in medieval Ashkenaz toward commercial litigation before "gentile" tribunals differed at times from approach towards the practice by Jewish communities in Northern Africa. ${ }^{71}$ A plausible explanation for this variance may be that non-Jewish tribunals in Ashkenaz, unlike Muslim communities in northern Africa, which viewed Jewish litigation in Muslim courts as an act of conversion or acceptance of Muslim supremacy, viewed such litigation in considerably more casual terms. ${ }^{72}$

Countless other interpretive innovations have come into being in the same way. One of the International Monetary Fund's mantras is that a precondition for economic development is the existence of predictable laws governing the marketplace and a legal regime that protects capital formation and ensures property rights. Noted institutional economists have built a career from this and related ideas concerning the significance of credible commitments to economic growth. ${ }^{73}$

Some two thousand years ago Hillel the Elder, a famous Jewish religious leader and scholar who lived in Jerusalem during the politically tumultuous time of King Herod the Great, introduced the revolutionary pruzbul, an institution that, notwithstanding the Jewish law concerning cancellation of debts in the sabbatical year, ensured the repayment of loans. The motive for introducing the pruzbul was the "repair of the world" (tikkun olam), that is, the repair of social

69 See, e. g., Јасов Katz, The “Shabbes Goy”: A Study in Halakhic Flexibility 56-59, 229 (1989); Jacob Katz, Alterations in the Time of the Evening Service (Ma'ariv) An Example of the Interrelationship between Religion Customs and their Social Background, in The Divine Law in Human Hands Case Studies in Halakhic FleXibility 88 (1998).

70 Louis Jacobs, A Tree of Life: Diversity, Flexibility, and Creativity in Jewish Law 117 (2000).

71 See supra note 2.

72 See Gideon Libson, Jewish and Islamic Law: A Comparative Study of Custom during the Geonic Period (2003).

73 See, e.g., Douglass C. North \& Barry R. Weingast, Constitutions and Commitment: The Evolution of Institutions Governing Public Choice in Seventeenth Century England, 29 J. Econ. Hist. 803-832 (1989); Barry R. Weingast, Constitutions as Governance Structures: The Political Foundations of Secure Markets, 149 J. Inst. Theoretical Econ. 286 (1993). 
and economic order; it both protected the creditor against the loss of his property and protected the needy against being refused loans of money due to fear of default. ${ }^{74}$ Other similar ingenuity ensued, such as the ceremonial sale to a non-Jew of chametz (bread, grains, and other leavened products) before Passover; the intensely debated "sale permit" (heiter mechira) that allows Jewish farmers in Israel to fictionally "sell" their land to non-Jews to permit the continuation of agricultural work during the seventh year (shnat shmita) of the seven-year agricultural cycle mandated by the Torah for the Land of Israel; ${ }^{75}$ and the legal fiction of eruv chatzerot - "mixed ownership of courtyards/ domains" - permitting observant Jews within the eruv to circumvent the prohibition against carrying children and belongings on the Sabbath. ${ }^{76}$ Or, in modern times, the invention of the Shabbat elevator (ma'alit Shabbat) - an elevator that is programmed to go up and down and stop at every floor by itself so that it can be used without violating the rules of the Jewish Sabbath. ${ }^{77}$

Jewish law is by no means unique in terms of creatively accommodating both religious precepts and concrete social needs and concerns. Shari'a, for example, renders impermissible the practice of usury or charging interest (riba). This is based on a moral objection to "unjust enrichment" or moneymaking without actual work. It is also meant to discourage borrowing, which is feared to be addictive and irresponsible. The classical approach to riba defines it as any increase over the nominal value of a sum lent. In the religious schools of interpretation this view is the most popular and, as such, exerts considerable pressure on governments attempting to Islamize their state or to align their banking practices with the tenets of Islam. An Islamic government that followed the classical approach would have to rid its banking practices of interest in any form. However, economic exchange is very constricted without interest-yielding credit. In pre-modern times this gave birth to the "double sell" - a practice whereby a loan is awarded alongside the transfer of another object to the borrower, with the agreement that the nominal value of the loan plus a grossly inflated price for the accompanying object (so that the portion of the price above the object's fair value serves as de facto interest) will be paid back to the lender. ${ }^{78}$

74 See R. Alfred S. Cohen, Pruzbul, 27 J. Halacha \& Contemporary Society 17 (1994).

75 See R. Yitzchok Gottlieb, Understanding the Heter Mechira, 25 J. Halacha \& ContemporaRy SOCIETY 5 (1993).

76 See R. Hershel Schachter, The Laws of Eruvin - An Overview, 5 J. Halacha \& Contemporary Society 5 (1983).

77 See R. Michael Broyde \& Rabbi Howard Jachter, The Use of Elevators and Escalators On Shabbat and Yom Tov, 29 J. Halacha \& Contemporary Society 62 (1995).

78 See Frank E. Vogel and Samuel L. Hayes III, Islamic Law and Finance: Religion, Risk, and Return 39 (2006); Mahmoud A. El-Gamal, Islamic Finance, Law Economics and Practice 70-71 (2006). 
In modern times a flexible, pragmatic, form-over-substance approach to Islamic banking has developed, with countless innovations in place that formally circumvent the prohibition on riba while ignoring the substantive moral basis of the prohibition. ${ }^{79}$ Several major banks in the Muslim world even employ clerics whose job is to ensure compliance of banking products with pertinent religious directives. Beyond this, some modern interpreters have suggested that whereas interest would be prohibited in an ideal world, the use of it as a temporary measure promotes the greater good and may be justified on the grounds of necessity. Some even argue that money and interest are modern concepts outside the scope of the riba prohibition, and that interest on moneylending is therefore permissible. ${ }^{80}$

Outside influence on doctrinal transformation may also take a broader "law and society" direction. As the renowned Talmudic scholar Marcus Jastrow notes, modern research into Talmudic literature has proven that there was a "marvellous familiarity of the rabbis with the events, institutions, and views of life of the world outside and around their own peculiar civilization." 81 And so, as the context within which Jewish law operated changed over time, so too did the strictness with which the concept (discussed earlier) of khukot ha'goy was interpreted. At times when Jewish religious identity did not face major threats, a lenient approach was adopted. In the twelfth century, for instance, Rabbi Eliezer of Metz (France) laid down a firm rule that the concept of khukot ha'goy only applies to the religious practices of gentiles, and that the mere fact that gentiles may engage in a certain practice does not in itself mean the practice is forbidden. ${ }^{82}$ On the other hand, in the face of credible emancipation threats and the rise of Reform Judaism in nineteenth-century Europe, the khukot ha'goy principle was invoked against the use of an organ in the synagogue, against adopting gentile names, against hunting animals for sport, against not growing a beard, and even against the wearing of a tie. ${ }^{83}$

Another creative solution to such threats to authentic Jewish identity are revealed when primary/secondary norm duality emerges in the jurisprudence of

79 See, e.g., Mahmoud A. El-Gamal, "Interest” and the Paradox of Contemporary Islamic Law and Finance, 27 FordHAM InT’L L. J. 108 (2003).

80 M. Raquibuz Zaman, Ususry (Riba) and the Place of Bank Interest in Islamic Banking and Finance, 6 InT’L J. Banking \& Finance (2008).

81 Marcus Jastrow, Dictionary, preface, p. xiii; cited in JACOBS, supra note 70, 80. See also IsRaEL M. Ta Shma, Halakha, Custom and Reality in Ashrenaz 1000-1350, at 185-88 (1996) [in Hebrew].

82 Yitshak Kahana, Judaism and the Non-Jewish Environment, in RESEARCH IN HA-TESHUvoT LITERATURE 306-316 (1973) [in Hebrew].

83 See JасовS, supra note 70, at 88-89. 
religious tribunals, such as can be identified in religious tribunals in present-day Israel. Here, rules that seem to hold similar legal functions are given different levels of interpretive import. As Daphna Hacker shows, Israeli rabbinical courts diverge far more in divorce disputes than in inheritance conflicts. ${ }^{84}$ While in the former, the rabbinical courts fight ardently to preserve their authority vis-à-vis the secular legal system (efforts that often include blatant violations of gender equality standards), they take a considerably more pragmatic position in the context of inheritance conflicts (including higher regard for gender equality standards). These findings correspond with Ayelet Shachar's distinction between the demarcating (identity-oriented) and distributive aspects of a religious tradition. ${ }^{85}$ Whereas the former aspect helps maintain a group's membership boundaries vis-à-vis the larger society (i.e., helps define the group and its members as such), the latter is more inwardly directed, as it shapes and allocates rights, duties, and ultimately powers among group members. The distinction between these two functions parallels the distinction between two legal aspects of divorce: the change made to personal status (the demarcating function) and the determination of property relations between spouses (the distributive function). While often intermingled in practice, personal status and property relations are legally two distinct subjects.

Other aggressively defensive retorts against engagement with the laws of others are detectable in earlier times. Uriel Simonsohn's comparative study of Christian and Jewish legal behavior under early Muslim rule (focusing on the late seventh to early eleventh centuries in the region between Iraq and present-day Tunisia) exposes considerable fluidity among different communities. Simonsohn shows how a disregard for religious affiliations threatened to undermine the position of traditional religious elites; and how, in response, they acted vigorously to reinforce communal boundaries, censuring recourse to external judicial institutions, and even threatening transgressors with excommunication. ${ }^{86}$ Resemblance to certain inward-looking "dichotomizing" positions within contemporary debates on the legitimacy of reference to the constitutive laws of others is not coincidental.

A clear illustration of broader societal influence on doctrinal change within Jewish law is the so-called "Maimonidean Controversy." This erupted in early thirteenth-century Spain and Provence following the dissemination of

84 Daphna Hacker, Religious Tribunals in Democratic States: Lessons from the Israeli Rabbinical Courts, 27 J. L. \& Religion 59 (2011). On similar trends in Malaysian religious tribunals, see Michael G. Peletz, Islamic Modern: Religious Courts and Cultural Politics in Malaysia (2002).

85 Ayelet Shachar, Multicultural Jurisdictions: Cultural Differences and Women’s Rights 49-54 (2001). 86 Uriel I. Simonsohn, A Common Justice: The Legal Allegiances of Christians and Jews Under Early IsLAm (2011). 
Maimonides' Guide for the Perplexed (Moreh Nevokhim) - widely regarded as the pinnacle and summary of the philosophical and halakhic tradition of the Golden Age of the Jews in Muslim Spain. ${ }^{87}$ The book was originally written in Arabic (1170-80), and was translated into Hebrew in 1204. The controversy involved the Maimonidean idea that God is omnipresent and incorporeal, and that any other view is heretical. At the heart of the controversy, however, was Maimonides' call for a substance-over-form interpretive approach to sacred precepts, and his notion that intellectual-philosophical idealism, not worship for the sake of worship, should be the main motivation for religious learning, indeed for leading a Torah-based life generally. It followed, under this reasoning, that general (as in non-Jewish) modes of philosophical inquiry, including methods of reasoning, comparison, analogy, and contrast, were acceptable reasoning tools for interpreting the Torah. ${ }^{88}$

As one would expect, Maimonides' radical ideas were not endorsed by the entire rabbinic establishment of his time. While they were well received by the generally liberal and cosmopolitan Sephardic Jewry (centered mainly in Toledo, Castile and Aragon), they were uncompromisingly rejected by the orthodox and largely "textualist" (mixed Ashekenazic-Sephardic) Jewry of Provence. A main accusation levelled against Maimonides was that his views undermined fundamental beliefs by formally endorsing them on the one hand but effectively subverting them through external interpretation that amounted to their negation. (One may think here of similar claims made in the very different context of contemporary debates in the United States concerning engagement with foreign constitutional law and interpretive approaches.) Maimonides' official embrace of the Jewish law traditional doctrine was not in line with his more philosophical views, which ultimately were "a cover for denial, or for insecure belief riddled with doubts." 89 So deep were the differences that some of the Ashkenazic rabbis were repeatedly denounced by Sephardic Jewish leaders as being insular zealots and narrow-minded "fools and lunatics with clogged minds who are devoted to superstitious nonsense and immersed in the fetid waters of unilluminated caves."90 Rabbi Solomon of Montpellier (Provence) emerged as the leader of the anti-Maimonidean movement, pronouncing a sentence of excommunication

87 See The Maimonidean Controversy, in 3 Eliezer Schweid, The Classic Jewish Philosophers: From SaAdia through the Renaissance 301 (Leonard Levin trans., 2008).

88 Id. See also David Berger, Judaism and General Culture in Medieval and Early Modern Times, in Judaism's Encounter with Other Cultures: Rejection or Integration? 57 (Jacob Schacter ed., 1997). 89 Id. at 306. A well-known critical account of the Maimonidean views, and of later Enlightenment Judaism more generally, is Leo Strauss, Philosophy and Law: Contributions to the Understanding of Maimonides and His Predecessors (1995).

90 Berger, supra note 88, at 118. 
on Maimonides' works, and later (in 1233), encouraging the Dominican Church leaders of Montpelier to publicly burn them. A bitter doctrinal war erupted, threatening to split the Jewish people. Ultimately, the Maimonidean ideas prevailed, but only after tremendous interpretive and political maneuvering spanning much of the thirteenth century, helped to mitigate the inter-communal tensions.

The different social context within which each of these communities lived mattered a great deal. In al-Andalus, in the parts of the Iberian Peninsula governed by the Muslim Moors from the eighth century to the fifteenth century, various dynasties of caliphs and emirs competed for political and military control. Islam was a key marker of collective identity. However, over prolonged periods a so-called Muslim-Jewish convivencia (coexistence) is said to have existed in al-Andalus. Although for much of its history al-Andalus was in conflict with Christian kingdoms to the north, within al-Andalus Muslims and Jews collaborated relatively peacefully (by medieval European standards) for centuries. Why? Unlike Jews in Christian Europe (including Provence), who were mostly isolated from the rest of the population in deplored professions such as money-lending, those in al-Andalus were well integrated into the Islamic marketplace, which was marked by a substantial degree of interdenominational cooperation. The Jews there lived as Dhimmis (protected non-Muslims living in a land governed by Muslims) and were granted a limited measure of religious and cultural autonomy, as well as jurisdictional autonomy in matters pertaining to their faith. This brought about an unprecedented cultural revival within the Jewish community, alongside increased cross-fertilization between Jewish and Muslim poets, commentators, and philosophers. In return, the Jews, as members of the Dhimmi caste, paid a special annual poll tax (jizya) to their protective rulers. This tax, higher than the tax Muslims had to pay, was at times one of the most important sources of income for the kingdom. At the same time, in several city-kingdoms (e. g. Córdoba and Toledo) translation programs were established under which Jews would translate Arabic books into Romanic languages, mainly Latin, and Greek and Hebrew texts into Arabic. In this way, many major works of Greek science and philosophy were translated into Arabic, and many accomplishments of the Moorish Empire in mathematics, medicine, botany, geography, astronomy, poetry, and philosophy were disseminated throughout the Christian world, contributing to the revival of these texts in the early Renaissance era. ${ }^{91}$

91 See Mark R. Cohen, The 'Convivencia' of Jews and Muslims in the High Middle Ages, in THE Meeting of Civilizations 54 (Moshe Ma’oz ed., 2009). 
In this context, Maimonides' outward-looking ideas, steeped in the philosophy and scientific insights of the time, reflected the general intellectual ambiance within which he worked. What is more, it was critically important for the minority Jewish communities in both Spain and Provence not to feel inferior to their respective host societies, be it with respect to cosmopolitanism in Spain or religious devotion in Ashkenaz. As scholars of medieval Jewry note, in Spain the resulting imitation "was cultural and intellectual"; in Ashkenaz, "given the different complexion of both majority and minority culture, it was a competition in religious devotion." 92 In the view of Rabbi Moses ben Nahman of Girondi (Nahmanides - the leading medieval Jewish scholar of the immediate post-Maimonides generation), Maimonides satisfied a major need among the Jews of Muslim Spain: Their immersion in the general culture of their environment brought about perplexity, but Maimonides responded to this confusion by arguing that philosophical inquiry and self-questioning, not blind following and obedience, are the basis for religious belief. ${ }^{93}$ This example demonstrates how a change to religion's approach to engagement with its surroundings, as in constitutional law, cannot be fully understood in isolation from the social and political context within which it evolves.

Many other intra-religious rifts throughout history revolved, at least ostensibly, around different attitudes toward external culture, laws, and moral principles; and they often do today. Recent divisions within the Anglican Church were spurred by conservatives' claims such as those of Peter Akinola, Anglican primate of the Church of Nigeria (2000-10), that the church was unwarranted in its openness to foreign, overly liberal, and supposedly inauthentic influences. ${ }^{94}$ In addition, the split has been characterized as one between two hemispheres, the "global south" and the "global north," with the church leadership traditionally coming from the latter camp, although the majority of church followers now come from the former. Although Akinola and others drew on ideology (a literal interpretation of the Bible) to support their position, they also accused the Church of England of attempting to maintain its colonial-era power over worshippers worldwide, and inappropriately inculcating "northern" liberalism in the more traditional South. ${ }^{95}$

92 Berger, supra note 88, at 121.

93 ScHweID, supra note 87, at 304.

94 See Evan F. Kuehn, Instruments of Faith and Unity in Canon Law: The Church of Nigeria Constitutional Revision of 2005, 10 Ecclesiastical L. J. 161 (2008).

95 Philip Jenkins, New faces of Christianity: Believing the Bible in the Global South 3-4 (2006). 
Two millennia earlier, the struggle between "authentic," "Hellenized," and later "Romanized" Judaism fuelled theological and political rifts in Judea, eventually leading to religious sectarianism among the Jews (e. g. the divisions between the Pharisees, Sadducees, and Essenes), the birth of Christianity in Judea, and the Roman invasion of the land by Titus. ${ }^{96}$ This took place in the politically charged context of the Hasmonean Kingdom (c. 164-63 BCE), amid dwindling Hellenic dominance in the region and, later, the struggle between the Hasmonean dynasty and King Herod the Great, a Roman client-ruler who advanced an amalgam of Judaic and Roman culture. So prevalent was foreign influence over the region that even prominent leaders of the Hasmonean Kingdom who formed an autonomous Jewish state in ancient Israel on an antiHellenic platform went by Hellenized or Romanized names such as Hyrcanus, Aristobulus, Alexander Jannaeus, and Salome Alexandra (Hebrew: Shlomtzion) the last of these the final leader of an independent Jewish state prior to the establishment of the State of Israel in $1948 .{ }^{97}$ Their successors later accused Herod the Great of being an inauthentic Jew, causing Jews to pejoratively refer to him as "the Idumean" - Ha'Edomi (his father was an Idumean who converted to Judaism). To date, the high Hebrew word for those who live a supposedly inauthentic life that is overly influenced by foreign culture is Mityavnim, literally meaning "those who live like the Greeks."

These and other similar examples highlight the conceptual affinity between the rejection of external sources by those who follow inward-looking interpretive approaches in constitutional and in religious law. So-called "originalists" in both religious and constitutional enterprises take the text to reflect the authentic and inerrant word of the pertinent authority. They, therefore. downplay the inevitable fluidity of interpretive practice and consciously seek to block its use. Explicit reference to external sources is perceived as bordering on the sinful. The text, they argue, has the ultimate authority by

96 The political science and sociology of religion literature is quite scant. The main primary sources are Flavius Josephus's The Jewish War (published c. 75 CE) and Antiquities of the Jews (published c. 94 CE). For more recent socio-religious accounts, see Richard A. Horsley, Scribes, Visionaries, and the Politics of Second Temple Judea (2007); Anthony J. J. Saldarini, Pharisees, Scribes, and Sadducees in Palestinian Society (1988); J. W. Lightley, Jewish Sects and Parties in the Time of Jesus (1925); and Julius Wellhausen, The Pharisees and the Sadducees: An Examination of Internal Jewish History (2001) (1874). See also Steven Fradde, Legal Fictions: Studies of Law and Narrative in the Discursive Worlds of Ancient Jewish Sectarians and Sages (2011).

97 Interestingly, Alexander Jannaeus himself, despite his Hasmonean views, allowed the city of Ashkelon to adhere to its Hellenistic culture for political reasons-his strategic interest in maintaining relationships with Egypt. 
virtue of being original - the actual words of the source that brought it into being. It should only be read as an authoritative record of the views of its drafters, with no implied invitation to subsequent interpreters to make their own judgments about the ideals reflected in it. This original-intent principle is seemingly more purist and authentic than any other interpretive practice; the interpreter is regarded as a guardian of the faith whose task is to convey the original textual meaning to future generations.

Manifestations of originalism in the Judaic tradition of interpreting religious directives are rare. Two exceptions are the ancient Sadducees and the "textualist" or "literalist" Kara'ites - a small movement that emerged in the ninth century that eschews rabbinic Judaism's emphasis on oral law and tradition (which emerged after the destruction of the Second Temple in Jerusalem (70 CE), combining written and oral interpretations through the evolving, living-tree Judaism discussed above). ${ }^{98}$ A possible explanation for the relative paucity of originalist tradition in Jewish law as compared to other major religions may be the "Diaspora thesis" - because Jews were stateless for two millennia and were spread across Europe, the Middle East and northern Africa, adaptive law and flexible interpretation were necessary to sustain religion. ${ }^{99}$

By contrast, fundamentalist approaches to interpreting the New Testament are quite common in North American Christianity. Likewise, the Salafist (or Wahhabist) movement in Islam insists that only the Prophet himself and the two generations following him should be relied on for spiritual guidance. Other somewhat less rigid but distinctly orthodox interpretive schools exist within virtually all of the world's religions. Unlike in the religious arena, originalism or textualism in constitutional interpretation, though extant, is far less common outside the United States. In any event, all these manifestations of

98 By contrast, the Kara'ite doctrine enshrines only the written Hebrew Bible (Torah, Nevi'im, K'tuvim, Hebrew acronym Tanach) as the sole constitutive religious authority.

99 On the diverse and pluralistic nature of Jewish law, see Hanina Ben-Menahem, Postscript: The Judicial Process and the Nature of Jewish Law, in An InTroduction to the History and Sources of Jewish Law 421 (N.S. Hecht et al. eds., 1996). On flexible interpretation in diasporic settings, see, e. g., Martin Baumann, A Diachronic View of Diaspora, and Significance of Religion and Hindu Trinidadians, in Diaspora, Identity and Religion: New Directions in Theory and Research (Carolin Alfonso, Waltraud Kokot \& Khachig Tölölyan eds., 2004). See generally RoBin Cohen, GLobal Diasporas: An Introduction (1997). As Baumann writes (id. at 173): "[I]n contrast to the prevalent view that the nature of a diaspora group is inherently conservative and traditional, keeping out all change, it is necessary to realize that adaptive modifications take place all the time, some sought after, some reluctantly accepted. Robin Cohen thus described a diaspora - apart from its negative connotations of homesickness and oppression - as a 'site of creativity'.” 
originalism take a doctrinal position that sharply differentiates them from other interpretive approaches. In virtually all interpretive contexts, calls against looking outside emerged as admonitions against what those making them perceived as inauthentic interpretative approaches rendering the community's boundaries overly porous. Although debates are cast in a purely interpretive guise, they often reflect sociopolitical divisions at least as much as they reflect ideational or jurisprudential factors. (The widely acknowledged link between America's decades long culture war and the fierce debate over the use of comparative legal materials in the United States Supreme Court as a contemporary illustration of such dynamic in action may come to mind). ${ }^{100}$

Virtually all originalist voices, whether in the "textualist" or "original intent" camp, claim to have a monopoly over the authentic reading of the original text, the meaning of it, or the original intentions of its framers; "nonoriginalist" interpretive schools, they argue, have drifted away from the authentic meaning of the text, and in doing so have inevitably incorporated extratextual influences. Any reference to foreign sources in interpreting a community's sacred, constitutive texts is thus perceived as illegitimate (how any contemporary interpretation of an old text may be free of such exogenous influences remains unclear, and is a contested issue). Fundamentalist sects of various sorts (e. g. "Torah-true” Naturei Karta Jews, hard-core Christian Reconstructionists, or the Shining Path radical Maoist guerillas in Peru) believe that their cause has crucial, almost near-cosmic importance. All of them, some admittedly more than others, see themselves as protecting not only a distinctive doctrine but also a vital principle and a way of life and of salvation. Some prefer to remain insular in their purist beliefs. Others locate their raison d'être in the proactive advancement of their cause against the grain of a hostile, loosely defined "system" or "outer world." Radical originalists are, by and large, critical of moral "contamination" in the wider culture. They tend to dismiss what they regard as relativism and to advance instead a rigid set of worldviews and beliefs based on unbending, simplistic dichotomies of good and bad, pure and corrupt, right and wrong, and just and unjust. Alternative interpretations of constitutive texts are viewed as inauthentic, theologically diluted, interest-driven, and often overinfused with considerations external to the faith's sovereign virtue.

Textualists often claim that doctrines said to be orally revealed and passed on are likely "to be invented by the priests, rabbis, qadis, or judges who claim to be transmitting them," and that "to admit oral tradition as a separate source is

100 See Mark V. Tushnet, Referring to Foreign Law in Constitutional Interpretation: An Episode in the Culture Wars, 35 U. Baltimore L. Rev. 299 (2006). 
to grant additional power to its institutional guardians and transmitters."101 Fundamentalist schools therefore erect a conceptual "wall of virtue" that protects their identity not only against other religions but also against what they deem irrelevant, nominal, contaminated, or even threatening versions of their own faith or cause. All uphold a sharp inward-outward distinction, whereby a limited number of texts, interpreters, and interpretive methods are sacred, with other possible sources or interpretations dismissed as external, a-contextual, misguided, and interest-driven rather than principled. Reference to these latter sources is immoral and deviant. Therein we see the affinity, in religion as well as in constitutionalism, between originalism and the tendency to despise close engagement with the constitutive laws of others; and conversely, between the "living tree" interpretive approach and the tendency to engage more closely with, and assign some moral authority to, foreign laws.

In summary, there are striking parallels between attitudes towards encounters with foreign law in constitutional law and in religious law. A combination of community survival instincts, theological innovation, and instrumentalist considerations guided engagement with the constitutive laws of others in much of the religion-steeped, pre-modern world.

\section{Conclusion}

When scientists search for life on other planets, they look for worlds that feature a set of preconditions understood as being conducive to sustainable life (water, oxygen, liveable climate, etc.). Comparative constitutionalists, by contrast, need not look any further than the nearest library. Pre-modern religious law (not religion) is, in several important respects, a mirror universe of constitutional law.

Constitutional law and religious law are often portrayed as diametrically opposed domains. But they have much more in common than first meets the eye. Both are revered symbolic systems that reflect ideals, aspirations, and principles that are larger than ordinary life. In both, a trade-off between interpretation and amendment seems to have existed, whereby the harder it is to alter the text, the greater the likelihood of interpretive wars over the text's true meaning. The challenge of when and how to engage with the laws of others - a challenge that comparative constitutional law has been grappling with over the last several decades - is something that religious law has been wrestling with for centuries,

101 Grey, supra note 62. 
perhaps millennia. Moreover, support for originalist, purposive, and living-tree interpretive schools is evident in both spheres. And neither domain is a purely reverent one. Constitutionalism and religion may both be forums of principle, but they are also domains of political strife, in which various stakeholders, interests, and worldviews fight for recognition, influence, and other gains. They operate within particular social, political, and economic contexts, and cannot be fully understood independently of those contexts. In particular, both domains feature sophisticated, and in many respects comparable, legacies involving engagement with the laws of others and translation of morally elevated, yet open-ended, texts into guidelines for public life.

Despite these striking similarities, there is a persisting tendency in comparative constitutional law to study the constitutional present while overlooking pertinent histories, near and far. ${ }^{102}$ Similarly, contemporary constitutional discourse about accommodation of religious difference in a liberal state assumes intellectual and normative superiority over religion, consequently ignoring the rich history of debates and innovation within religious law concerning the treatment of the laws of others. This avoidance by constitutional scholars is driven by a variety of doctrinal and socio-cultural factors, primary among them is the conventional construct of constitutional law as a modern, rule-of-law enterprise that showcases reason, unlike religious law, an outdated, rule-ofGod enterprise of belief. While there are undoubtedly important differences between these two realms, the simplistic portrayal of religious law as outdated and, thus, altogether irrelevant to contemporary discussions about the laws of others provides an all-too-easy excuse for contemporary constitutional discourse to blind itself to religious law's rich history and tremendous doctrinal innovation. While some or even most of this wealth of knowledge may not be pertinent in present-day debates about accommodation of difference by the modern state, the dismissal of pre-modern religious law as an altogether irrelevant enterprise appears driven more by factors involving doctrinal and culture wars than by intellectual honesty. Regardless, it reflects a somewhat thin scholarly culture, and perhaps, also, a missed opportunity to break out of the traditional confines of the case law method as the dominant mode of inquiry in constitutional law. Alongside other possible new horizons of comparative inquiry, ${ }^{103}$ religious law

102 Undoubtedly, scholars of religious law are no more universalist than their constitutional counterparts, and, more often than not, tend to exemplify particularism - but they at least readily admit to their parochial inclinations.

103 See, e.g., Ran Hirschl, From Comparative Constitutional Law to Comparative Constitutional Studies, 11 InT’L J. Const. L. 1 (2013). 
provides what appears to be very fertile terrain for placing contemporary debates in (comparative) constitutional law in a broader, richer, and more sophisticated context.

More specifically, few authors have paid close attention to the potential value of legal concepts developed within religious law to meeting the challenge of encounters with foreign law. Even fewer have drawn analogies between the effect of extradoctrinal factors on interpretation in the two domains. Given the exceptional richness of the interpretive sparring that has occurred in religious law through the ages, the meagre references to it by contemporary comparativists and constitutional theorists may be portrayed as intellectually sinful. The poignant dilemmas of rejection of or interaction with foreign law yearn for thorough and prompt crossdisciplinary analysis, as their relevance to contemporary constitutional law comes to echo their historic importance in religious law.

Acknowledgment: I thank the Journal's editors and anonymous reviewers for their helpful suggestions, Michele Manspeizer for her quality editorial assistance as well as Ayelet Shachar and Marinka Yossiffon for their exceptionally valuable comments on an earlier draft. 